\title{
OBSERVATION OF PARASITIC BEHAVIOUR OF AN INVASIVE NEOZOOTIC FISH SPECIES, THE TOPMOUTH GUDGEON, PSEUDORASBORA PARVA (ACTINOPTERYGII: CYPRINIFORMES: CYPRINIDAE), ON OTHER CYPRINID FISHES
}

\author{
Martin OBERLE ${ }^{1}$, Jan MÁSÍLKO ${ }^{1,2 *}$, and Helmut WEDEKIND ${ }^{1}$ \\ ${ }^{1}$ Bavarian State Research Center for Agriculture, Institute for Fisheries, Department for Carp Farming, Hoechstadt \\ a. d. Aisch, Germany \\ ${ }^{2}$ South Bohemian Research Center of Aquaculture and Biodiversity of Hydrocenoses, Institute of Aquaculture and \\ Protection of Waters, Faculty of Fisheries and Protection of Waters, University of South Bohemia \\ in Ceske Budejovice, České Budějovice, Czech Republic
}

Oberle M., Másílko J., Wedekind H. 2019. Observation of parasitic behaviour of an invasive neozootic fish species, the topmouth gudgeon, Pseudorasbora parva (Actinopterygii: Cypriniformes: Cyprinidae), on other cyprinid fishes. Acta Ichthyol. Piscat. 49 (2): 171-176.

\begin{abstract}
The objective of this study was to observe and document behavioural factors of parasitism of an invasive neozootic fish species - the topmouth gudgeon, Pseudorasbora parva (Temminck et Schlegel, 1846) on different cohorts of 1-year-old and 2-year-old common carp, Cyprinus carpio Linnaeus, 1758, as well as 3 -year-old tench, Tinca tinca (Linnaeus, 1758), after the overwintering period in ponds and subsequently in aquaria. Fishes cohabited the ponds for seven months and the aquaria for one month. After this period carp and tench were examined for visible lesions on the body surface. During the cohabitation period cyprinids were actively nibbled by the neozootic fish species $P$. parva. Such attacking or nibbling caused injuries on the skin and deep lesions, which can be interpreted as predation or even parasitism.
\end{abstract}

Keywords: fish parasitism, fish as parasite, Cyprinus carpio, neozoa, Tinca tinca, Pseudorasbora parva

\section{INTRODUCTION}

The topmouth gudgeon, Pseudorasbora parva (Temminck et Schlegel, 1846), is a small cyprinid fish species, which is non-native to Europe. According to Berg (1964) it originates from the south-eastern parts of the former Soviet Union and eastern China. The fish was accidentally introduced to Europe in the 1960s during the import of herbivorous fish species (Adámek and Siddiqui 1997) as feed for predatory fishes in hatcheries (Cakic et al. 2004) or occasionally as an ornamental species (Beyer 2004). The details of invasion, in terms of introduction, distribution, and spreading of $P$. parva across Europe were earlier summarized by Gozlan et al. (2010).

A high degree of invasive potential, rapid colonization of new bodies of water, and many other successful behavioural and life strategies of $P$. parva are described in many papers (Katano and Maekawa 1997, Gozlan et al. 2002, 2010, Pinder et al. 2005, Britton and Brazier 2006, Beyer et al. 2007, Yan and Chen 2009, Záhorská and Kováč 2009, Britton et al. 2010). This well-known, highly invasive potential of $P$. parva has a negative impact on native fish species. Lusk et al. (2010) stated that P. parva caused problems to the indigenous cyprinids populations in a small water body, and that it is a strong food competitor for indigenous species (Adámek and Sukop 2000, Oberle unpublished $^{* *}$ ). These findings were confirmed by Musil et al. (2014) who reported that invasive P. parva negatively impacted carp production by its marked grazing pressure on natural food and subsequent unfavourable economic effect in carp farming.

Moreover, a few other studies indicated that with the high density and age, $P$. parva exhibits a behaviour which can be interpreted as predation or even facultative parasitism affecting other fish species (Trombitskiy and Kakhovskiy 1987, Libosvárský et al. 1990). Such behaviour may lead to far-reaching consequences in terms of the fish welfare in general and health status of cultivated fish species in particular (Conte 2004, Barber 2007). It may also have a negative economic effect on pond aquaculture in Europe. Unfortunately, the above-

\footnotetext{
* Correspondence: Dipl.-Ing. Jan Másílko, Ph.D., Bayerische Landesanstalt für Landwirtschaft Institut für Fischerei (IFI 2), Außenstelle für Karpfenteichwirtschaft, Greiendorfer Weg 8, 91315 Höchstadt, Germany, phone: (+49) 091935089011, e-mail: (JM) jan.masilko@lfl.bayern.de, (MO) martin.oberle@lfl.bayern.de, (HW) helmut.wedekind@lft.bayern.de.

** Oberle M. 2003. High incidence of topmouth gudgeon (Pseudorasbora parva) reduces yield carp ponds. In: European Network for the Dissemination of Aquaculture RTD Information (Q5CA-2000-30105). Aqua-Flow ref: TL2003-128.
} 
mentioned antagonistic relations of $P$. parva with native fish species of Europe are currently poorly documented.

The objective of this study was to observe and document the aggressive behaviour of Pseudorasbora parva towards common carp, Cyprinus carpio Linnaeus, 1758 and tench, Tinca tinca (Linnaeus, 1758), and to analyse its nature and extent of the inflicted pathology.

\section{MATERIALS AND METHODS}

Pond trial. Pond trials were conducted between October 2005 and April 2006 in six 1-m deep earthen ponds of the surface area ranging from 200 to $250 \mathrm{~m}^{2}$ (IFI Höchstadt/ Aisch, Bavaria, Germany). All ponds were stocked with $0.6 \mathrm{~kg}$ fish $\cdot \mathrm{m}^{-2}$ of different cohorts (mean weight: 1-yearold carp $\approx 28 \mathrm{~g}$; 2-year-old carp $\approx 260 \mathrm{~g}, 3$-year-old tench $\approx$ $128 \mathrm{~g}$ ) without any visible lesions, with weight ratio $10 \%$, $65 \%$, and $25 \%$, respectively. Such stocking density was consistent with normal overwintering practices in German carp pond aquaculture. Two ponds (Group A) were used as control group (without P. parva); two ponds (Group B) were stocked with smaller P. parva (total length $4.4 \pm$ $2.1 \mathrm{~cm}$, weight $1.1 \pm 1.0 \mathrm{~g}$, biomass $0.15 \mathrm{~kg} \cdot \mathrm{m}^{-2}$ ); and two ponds (Group C) were stocked with bigger $P$. parva (total length $7.8 \pm 1.0 \mathrm{~cm}$, weight $4.4 \pm 2.2 \mathrm{~g}$, biomass $0.15 \mathrm{~kg}$. $\mathrm{m}^{-2}$ ). During wintertime, the ponds were covered with ice and snow for approximately 4 months. The water inflow was $0.2 \mathrm{~L} \cdot \mathrm{s}^{-1}$ from a ground well. During wintering, fish were not fed and basic water quality parameters were monitored. Water temperature $\left({ }^{\circ} \mathrm{C}\right)$, dissolved oxygen $\left(\mathrm{mg} \cdot \mathrm{L}^{-1}\right)$, and $\mathrm{pH}$ were measured in situ using a WTW multimeter (Multi 3410, Weilheim, Germany); pH was measured using a WTW pH-meter (3110, Weilheim, Germany). Ammonium $\left(\mathrm{NH}^{4+}\right)$ concentration $\left(\mathrm{mg} \cdot \mathrm{L}^{-1}\right)$ was measured semi-quantitatively (colorimetric method according to Nessler) by visual comparison with the colour of the measurements solution with a reference card display (MColortestTM Merck KGaA, Darmstadt, Germany).

Fish of each species and cohort (1-year-old carp, 2-yearold, 3-year-old tench) from each pond were randomly sampled after 6 months. Fishes were examined for the presence of skin lesions. Skin irregularities that could be assigned to P. parva were counted and analysed: the diameter and depth of the lesions were measured using a calliper.
Aquarium trial. Later in 2010 an aquarium trial was performed with a similar setup at the University of South Bohemia in Ceske Budejovice, Faculty of Fisheries and Protection of Waters. The study was conducted according to the principles of the Ethical Committee for the Protection of Animals in Research of the University of South Bohemia, Research Institute of Fish Culture and Hydrobiology Vodnany (based on the EU-harmonized animal welfare act of the Czech Republic). Six 50-L aquaria (Aqua A-F) were stocked with one healthy (intact skin and fins, without any visible lesions) fish of each cohort (1-year-old carp, 2-year-old carp, and 3-yearold tench). Two aquaria (Group A) were used as control groups without $P$. parva. Other two aquaria (Group B) were stocked with smaller P. parva and the last two aquaria were stocked with bigger $P$. parva (Group C). In addition, $P$. parva in control aquaria were replaced by small common carp or alternatively European perch, Perca fluviatilis Linnaeus, 1758, to achieve the same stocking densities of cohabitated fish species-biomass of approximately $87 \mathrm{~g}$ per aquarium. All cohabiting fish species in each aquarium are described in Table 1. This aquarium trial was conducted only for the visual documentation of fish behavioural interaction (fishes were monitored, observed, and photographed) and to confirm our hypothesis of facultative parasitism of P. parva from the pond data. During the trial, fish were not fed. Basic water quality parameters were monitored from 28 November to 28 December 2010 . Water temperature $\left({ }^{\circ} \mathrm{C}\right)$, dissolved oxygen $\left(\mathrm{mg} \cdot \mathrm{L}^{-1}\right)$, and $\mathrm{pH}$ were measured in situ using a YSI Professional Plus multimeter (YSI Incorporated, Yellow Springs, $\mathrm{OH}$, USA). Ammonium $\left(\mathrm{NH}^{4+}\right)$ concentration $\left(\mathrm{mg} \cdot \mathrm{L}^{-1}\right)$ was measured semi-quantitatively (colorimetric method according to Nessler) by visual comparison with the colour of the measurements solution with a reference card display (MColortestTM, Merck KGaA, Darmstadt, Germany).

\section{RESULTS}

Pond trial. At the time of harvesting, various lesions on fish skin were observed and measured. Only three individuals (3.2\%) of 2-year-old carp in Group A (without P. parva) had lesions (Table 2). Lesions on the body of other 2-yearold carp and other fish species in Group A have not been

Length and weight of fish species used in cohabitation studies with Pseudorasbora parva

Table 1 (aquarium trial of 2010)

\begin{tabular}{cclccc}
\hline Group & Aquarium code & Cohabiting fish species & $N$ & TL $[\mathrm{cm}]$ & BW $[\mathrm{g}]$ \\
\hline \multirow{2}{*}{ A } & Aqua A & Cyprinus carpio & 10 & $7.9 \pm 1.0$ & $8.8 \pm 2.9$ \\
& Aqua D & Perca fluviatilis & 16 & $8.4 \pm 0.7$ & $5.5 \pm 1.2$ \\
\multirow{2}{*}{ B } & Aqua B & Pseudorasbora parva & 76 & $4.3 \pm 1.3$ & $1.1 \pm 0.7$ \\
& Aqua E & Pseudorasbora parva & 101 & $4.1 \pm 1.2$ & $0.9 \pm 0.6$ \\
\multirow{2}{*}{ C } & Aqua C & Pseudorasbora parva & 15 & $8.6 \pm 0.5$ & $5.8 \pm 0.8$ \\
& Aqua F & Pseudorasbora parva & 15 & $8.5 \pm 0.4$ & $5.8 \pm 1.0$ \\
\hline
\end{tabular}

Data represents mean values \pm standard deviation; $N=$ number of individuals, TL $=$ total length, $\mathrm{BW}=$ body weight; Group A = control (without $P$. parva), Group B = cohabitating with small P. parva, Group $\mathrm{C}=$ cohabiting with bigger $P$. parva; the fish used were: 1-year-old carp, 2-year-old carp, and 3-year-old tench. 
observed. In line with our findings in the pond trial, in the aquaria trial no lesions on the body of the fish from aquaria without $P$. parva were observed. Fish in Group B (smaller P. parva) had more lesions on the body compared to Group $\mathrm{C}$ and especially compared to Group A (Table 2). Moreover, the experimental fish had from one up to six lesions of different size and depth on both body sides. The diameter and the depth of visible lesions of different fish species are presented in Table 3. In Group A, only three individuals of 2-year-old carp showed only one lesion (Table 2). In Group $\mathrm{B}, 31$ individuals of 1-year-old carp showed at least one lesion and only one individual of 1-year-old carp had two lesions. In the same Group B, 66 individuals of the 2-yearold carp showed at least one lesion. Of these, 22 individuals had at least two lesions and one individual of 2-year-old carp had five lesions. In this Group B, 73 individuals of the 3-year-old tench had at least one lesion, 14 individuals of them had at least two lesions, and only three individuals of the 3-year-old tench had three lesions. In Group C (bigger P. parva) 16 individuals of the 1-year-old carp showed at least one lesion (Table 2). In addition, only one individual of the 1-year-old carp had a second lesion. A total of 49 individuals of 2-year-old carp in Group $\mathrm{C}$ showed at least one lesion on their muscle tissue (Table 2). Eleven individuals of the latter had at least two lesions and in one case, one individual of 2-year-old carp had even six lesions. A total of 49 individuals of the 3-year-old tench showed at least one lesion in Group C (Table 2), of which seven individuals had a second lesion. Maximum of three lesions were observed on the skin of 3-year-old tench.

In the majority of cases, the lesions were located behind and below the base of the dorsal fin and at the base

Table 2

Frequency of lesions on the body of different fish species cohabiting (or not) with Pseudorasbora parva observed in ponds after the winter of 2005/2006

\begin{tabular}{cccccccccc}
\hline \multirow{2}{*}{ Fish } & \multicolumn{3}{c}{ Group A } & \multicolumn{3}{c}{ Group B } & \multicolumn{3}{c}{ Group C } \\
\cline { 2 - 9 } & $N$ & $n$ & {$[\%]$} & $N$ & $n$ & {$[\%]$} & $N$ & $n$ & {$[\%]$} \\
\hline 1-year-old carp & 45 & 0 & 0 & 90 & 31 & 34.4 & 90 & 16 & 17.8 \\
2-year-old carp & 90 & 3 & 3.3 & 90 & 66 & 73.3 & 90 & 49 & 54.4 \\
3-year-old tench & 90 & 0 & 0 & 90 & 73 & 81.1 & 90 & 49 & 54.4 \\
\hline
\end{tabular}

Group $\mathrm{A}=$ control (without $P$. parva), Group $\mathrm{B}=$ cohabiting with small $P$. parva, Group $\mathrm{C}=$ cohabiting with bigger $P$. parva, $N=$ number of fish examined, $n=$ number of fish with lesions. of the caudal fin (Figs. 1 and 2), but were also found at different parts all over the fish body. For example, lesions were observed around the anus, around the base of the anal fin, and around the base of pectoral and pelvic fins. In single individuals, the ventral part of the head next to the mouth was affected. All of these lesions were observed on both sides of the body.

Aquarium trial. No lesions in fish from aquaria without P. parva (Group A) were observed. The first cases of aggressive behaviour were recorded after two days, especially in aquaria with smaller P. parva (Group B). The bigger $P$. parva (Group C) started their nibbling on 2-year-old carp on day 10 . The nibbling started mostly at the base of the dorsal fin, caudal, pectoral, ventral fin, and very seldom at the base of anal fin. Repeated action by P. parva aiming at the same location at the base of dorsal fin finally led to larger lesions, which were reaching deeper, into the muscle tissue (Fig. 1). The nibbling of $P$. parva on cyprinids was observed and documented on photographs (Fig. 2). Basic water parameters were found to be within the recommended range for cyprinids, except for temperature, which was generally low in both trials (Table 4).

\section{DISCUSSION}

The presently reported study provides evidence of a relation between the neozootic fish species Pseudorasbora parva and other cyprinids fishes. While it is well known that $P$. parva has a wide range of accepted food items including detritus, periphyton, zooplankton, and zoobenthos (Trombitskiy and Kakhovskiy 1987, Adámek and Siddiqui 1997). Trombitskiy and Kakhovskiy (1987) described another aspect of their feeding plasticityfacultative parasitism on other fish species. The affected cyprinids showed lesions on the epidermis, from dorsal to vertical fin. In some individuals, the muscle tissue was consumed as well. The damages occurred at high stocking densities and during food shortage for $P$. parva (Trombitskiy and Kakhovskiy 1987). This was confirmed by our observations. Lesions were found at different parts on both sides of fish bodies, mainly around bases of fins (Figs. 1 and 2). The general appearance of the lesions on carp skin (Fig. 1) was similar to those occurring in the course of erythrodermatitis (a bacterial disease). The absence (or low frequency) of the lesions in the control group, suggests that the reason for the observed skin damage were not bacteria. Some lesions (Fig. 2) features signs of a secondary fungal infection, which may suggest

Table 3

Diameter and depth of apparent lesions on the body of different fish species cohabiting (or not) with Pseudorasbora parva observed in ponds after the winter of 2005/2006

\begin{tabular}{lcccccc}
\hline \multirow{2}{*}{ Fish species } & \multicolumn{2}{c}{ Group A } & \multicolumn{2}{c}{ Group B } & \multicolumn{2}{c}{ Group C } \\
\cline { 2 - 7 } & Diameter [cm] & Depth [cm] & Diameter [cm] & Depth [cm] & Diameter [cm] & Depth [cm] \\
\hline 1-year-old carp & none & none & $0.8 \pm 0.3$ & $0.2 \pm 0.1$ & $0.4 \pm 0.2$ & $0.2 \pm 0.1$ \\
2-year-old carp & $1.0 \pm 0.5$ & $0.2 \pm 0.1$ & $1.9 \pm 0.9$ & $0.4 \pm 0.2$ & $1.4 \pm 0.8$ & $0.3 \pm 0.2$ \\
3-year-old tench & none & none & $0.8 \pm 0.4$ & $0.2 \pm 0.1$ & $0.9 \pm 0.5$ & $0.2 \pm 0.1$ \\
\hline
\end{tabular}

Group A = control (without $P$. parva), Group B = cohabiting with small P. parva, Group $\mathrm{C}=$ cohabiting with bigger $P$. parva. 
Table 4

Basics water quality parameters measured in situ in two different trials: pond trial (2005/2006) and aquarium trial

(2010)

\begin{tabular}{lcccc}
\hline \multicolumn{1}{c}{ Trial } & $\begin{array}{c}\text { Temperature } \\
{\left[{ }^{\circ} \mathrm{C}\right]}\end{array}$ & $\begin{array}{c}\text { Dissolved oxygen } \\
{\left[\mathrm{mg} \cdot \mathrm{L}^{-1}\right]}\end{array}$ & $\mathrm{pH}$ & $\begin{array}{c}\text { Ammonium }\left(\mathrm{NH}^{4+}\right) \\
{\left[\mathrm{mg} \cdot \mathrm{L}^{-1}\right]}\end{array}$ \\
\hline Pond trial & $5.1 \pm 3.4$ & $14.7 \pm 5.5$ & $8.4 \pm 0.2$ & $0.1 \pm 0.0$ \\
Aquarium trial & $12.5 \pm 1.2$ & $7.8 \pm 1.0$ & $8.3 \pm 0.1$ & $1.1 \pm 0.4$ \\
\hline
\end{tabular}

Data represent mean values \pm standard deviation.

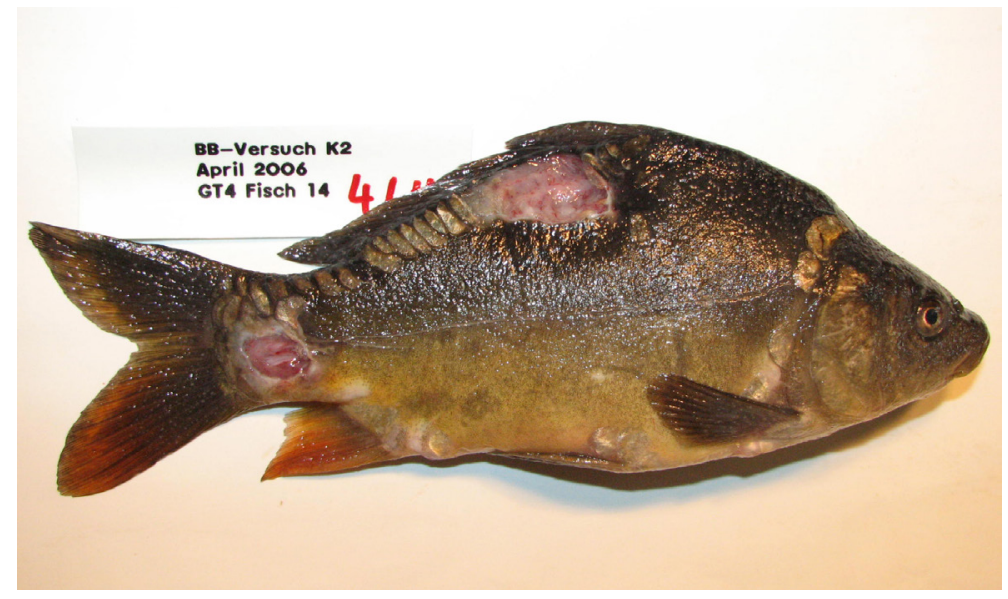

Fig. 1. Deep and large lesions in the skin of common carp Cyprinus carpio, attributed to persistent attacks/nibbles of Pseudorasbora parva, as observed after the pond trial in April 2006; the general appearance of the lesions on carp skin was similar to those occurring in the course of erythrodermatitis (a bacterial disease); the absence (low frequency) of the lesions in control group, suggests that the reason for the observed skin damage were not bacteria

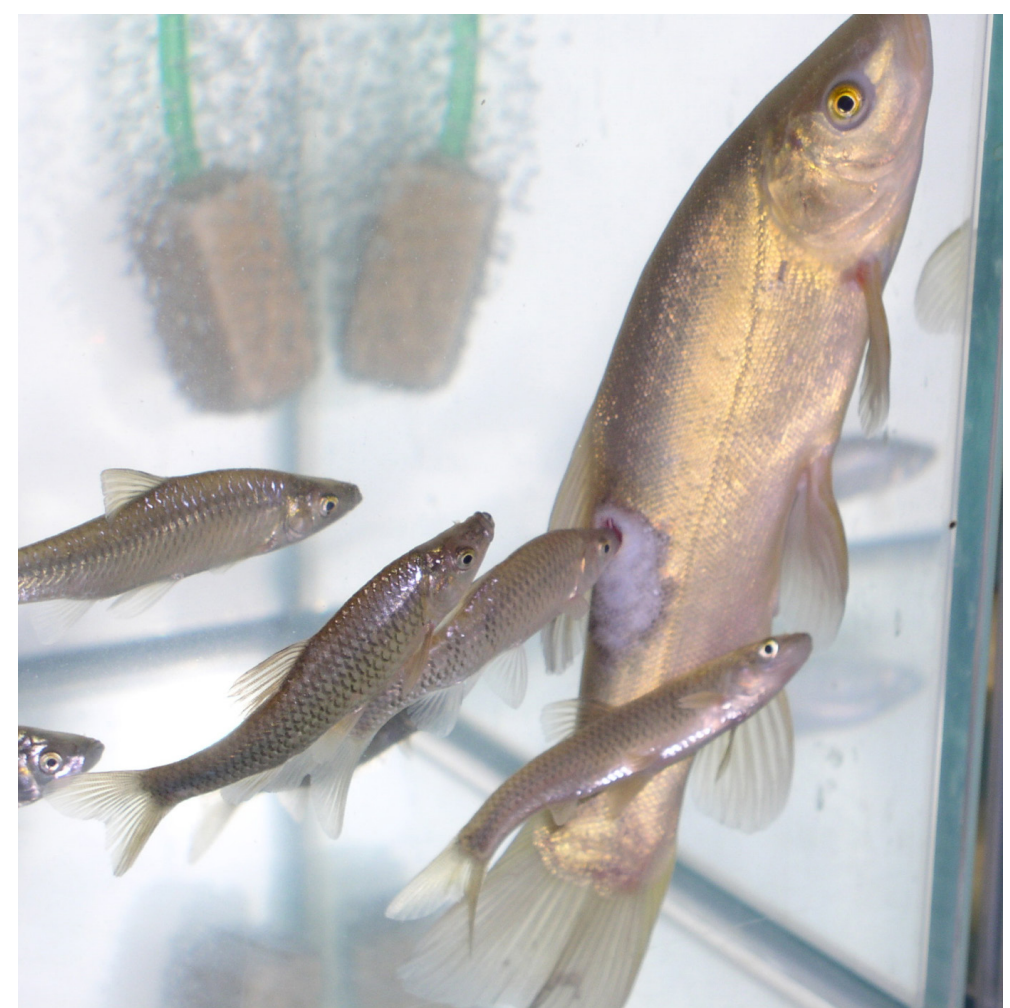

Fig. 2. Bigger Pseudorasbora parva (Group C) actively devouring tissue from an open lesion in the skin of a tench, Tinca tinca, in the aquarium trial; note a secondary fungal infection around the lesion 
that the fish affected were generally weakened and thus more susceptible to other pathogens.

During the winter period in central Europe, food availability from natural sources (zoo/phyto plankton) in ponds is generally low. Further, the stocked P. parva density of $0.15 \mathrm{~kg} \cdot \mathrm{m}^{-2}$ may be considered high. Combined with the lack of natural food resources, the observed attacks of P. parva on other fish species are likely a behavioural reaction to food scarcity. That could be a reason why fishes cohabiting with $P$. parva had a higher number of of lesions on the body compared to the group without $P$. parva (Table 2). Moreover in the group with smaller P. parva (pond trial) a higher frequency of lesions on fish bodies was observed. This is consistent with our aquarium trial observations. In the aquaria experiment, no lesions in fish from aquaria without P. parva (Group A) were observed. Similarly, as in the pond trial, a higher frequency of fish-body lesions was observed in the group with smaller $P$. parva in the aquaria. Moreover in this Group B (smaller $P$. parva) first cases of aggressive behaviour were recorded earlier compare to Group C (bigger P. parva). That suggests that stocking densities might affect predation activity of P. parva. Because Group B (smaller P. parva) was stocked with five-times to seven-times higher number of $P$. parva individuals compared to group C (bigger P. parva). As the density was determined by biomass of approximately $87 \mathrm{~g}$ of $P$. parva per aquarium.

Furthermore, Trombitskiy and Kakhovskiy (1987) stated, that small $P$. parva (age class $0+$ ) did not cause lesions in other fish. This statement was further investigated by Libosvárský et al. (1990) by analysing mouth constitution of $P$. parva at several age classes. Their study concluded that older $P$. parva could graze on larger fish because of the bigger stoma, increased size of lip epithelium, and as well as a stronger calcification of the jaws (Libosvárský et al. 1990). Our observations in the aquaria confirmed this hypothesis, where larger sized $P$. parva (total length: $4.1 \pm 1.2 \mathrm{~cm}$ to $8.6 \pm 0.5 \mathrm{~cm}$ ) were able to feed on bigger cyprinid fishes (carp and tench).

The observed antagonistic relation of $P$. parva with other fish species is evidently a stable, semipermanent relation with one organism benefiting from it and the other one evidently suffering because of the body damage. This relation was not resulting in the direct killing of the attacked fish. It is, therefore not predation but evidently parasitism because the former is usually a short, temporary relation (terminating with the death of the prey) while the latter is a permanent or semi-permanent relation between the parasite and the host. This particular case of parasitism can be further categorized as a facultative parasitism one because P. parva can otherwise feed on alternative food.

In summary, invasive Pseudorasbora parva has a large ecologic-behavioural plasticity and the phenomenon of the facultative parasitism was observed in relation to common carp and tench. It was documented that native cyprinid fish were actively attacked/gnawed/nibbled by $P$. parva - a neozootic fish species. This attacking or nibbling caused injuries to the skin and deep lesions in the muscle. The observed parasitism may have a negative impact not only on pond fishes but also on other species of the indigenous ichthyofauna, once $P$. parva is introduced and acclimatized. At least, this aggressive behaviour can have an extremely negative effect on commercial fish species in pond aquaculture, especially with respect to its economic sustainability. The extent to which the biological invasion of $P$. parva has an impact on other fish species needs to be investigated. Also for future investigation, the effects of different stocking densities on predation of P. parva should also be examined. Moreover, further investigations about how to avoid or minimize this problem are suggested as well.

\section{ACKNOWLEDGEMENTS}

We like to thank $\mathrm{Mr}$ Westphal for his various photographs. The study was financially supported by the Ministry of Education, Youth and Sports of the Czech Republic - project CENAKVA (LM2018099).

\section{REFERENCES}

Adámek Z., Siddiqui M.A. 1997. Reproduction parameters in a natural population of topmouth gudgeon, Pseudorasbora parva, and its condition and food characteristics with respect to sex dissimilarities. Polskie Archiwum Hydrobiologii 44 (1-2): 145-152.

Adámek Z., Sukop I. 2000. Vliv střevličky východní (Pseudorasbora parva) na parametry rybničního prostředí. [The impact of topmouth gudgeon (Pseudorasbora parva) populations upon pond environmental determinants.] Pp. 37-43. In: Biodiverzita Ichtyofauny České republiky 3. Brno: Ústav biologie obratlovců AV ČR. [In Czech.]

Barber I. 2007. Parasites, behaviour and welfare in fish. Applied Animal Behaviour Science 104 (3-4): 251264. DOI: $10.1016 /$ j.applanim.2006.09.005

Berg L.S. 1964. Freshwater fishes of the U.S.S.R. and adjacent countries: Volume 2. Israel Program for Scientific Translations, Jerusalem, Israel.

Beyer K. 2004. Escapees of potentially invasive fishes from an ornamental aquaculture facility: The case of topmouth gudgeon Pseudorasbora parva. Journal of Fish Biology 65 (Suppl. 1): 326-327. DOI: 10.1111/j.0022-1112.2004.00559ac.x

Beyer K., Copp G.H., Gozlan R.E. 2007. Microhabitat use and interspecific associations of introduced topmouth gudgeon Pseudorasbora parva and native fishes in a small stream. Journal of Fish Biology 71 (Suppl. D): 224-238. DOI: 10.1111/j.1095-8649.2007.01677.x

Britton J.R., Brazier M. 2006. Eradicating the invasive topmouth gudgeon, Pseudorasbora parva, from a recreational fishery in northern England. Fish Management and Ecology 13 (5): 329-335. DOI: 10.1111/j.1365-2400.2006.00510.x

Britton J.R., Davies G.D., Harrod C. 2010. Trophic interactions and consequent impacts of the invasive fish Pseudorasbora parva in a native aquatic foodweb: A field investigation in the UK. Biological Invasions 12 (6): 1533-1542. DOI: 10.1007/s10530-009-9566-5 
Cakic P., Lenhardt M., Kolarevic J., Mickovic B., Hegedis A. 2004. Distribution of the Asiatic cyprinid Pseudorasbora parva in Serbia and Montenegro. Journal of Fish Biology 65 (5): 1431-1434. DOI: 10.1111/j.0022-1112.2004.00525.x

Conte F.S. 2004. Stress and the welfare of cultured fish. Applied Animal Behaviour Science 86 (3-4): 205223. DOI: $10.1016 /$ j.applanim.2004.02.003

Gozlan R.E., Andreou D., Asaeda T., Beyer K., Bouhadad R., Burnard D., Caiola N., Cakic P., Djikanovic V., Esmaeili H.R., Falka I., Golicher D., Harka A., Jeney G., Kováč V., Musil J., Nocita A., Povz M., Poulet N., Virbickas T., Wolter C., Tarkan A.S., Tricarico E., Trichkova T., Verreycken H., Witkowski A., Zhang C.G., Zweimueller I., Britton J.R. 2010. Pan-continental invasion of Pseudorasbora parva: Towards a better understanding of freshwater fish invasions. Fish and Fisheries 11 (4): 315-340. DOI: 10.1111/j.1467-2979.2010.00361.x

Gozlan R.E., Pinder A.C., Shelley J. 2002. Occurrence of the Asiatic cyprinid Pseudorasbora parva in England. Journal of Fish Biology 61 (1): 298-300. DOI: 10.1111/j.1095-8649.2002.tb01755.x

Katano O., Maekawa K. 1997. Reproductive regulation in the female Japanese minnow, Pseudorasbora parva (Cyprinidae). Environmental Biology of Fishes 49 (2): 197-205. DOI: 10.1023/A:1007314817526

Libosvárský J., Baruš V., Štěrba O. 1990. Facultative parasitism of Pseudorasbora parva (Pisces). Folia Zoologica 39 (4): 355-360.
Lusk S., Lusková V., Hanel L. 2010. Alien fish species in the Czech Republic and their impact on the native fish fauna. Folia Zoologica 59 (1): 57-72. DOI: 10.25225/ fozo.v59.11.a9.2010

Musil M., Novotná K., Potužák J., Hůda J., Pechar L. 2014. Impact of topmouth gudgeon (Pseudorasbora parva) on production of common carp (Cyprinus carpio) - Question of natural food structure. Biologia 69 (12): 1757-1769. DOI: 10.2478/s11756-014-0483-4

Pinder A.C., Gozlan R.E., Britton J.R. 2005. Dispersal of the invasive topmouth gudgeon, Pseudorasbora parva in the UK: A vector for an emergent infectious disease. Fisheries Management and Ecology 12 (6): 411-414. DOI: 10.1111/j.1365-2400.2005.00466.x

Trombitskiy I.D., Kakhovskiy A.E. 1987. On the facultative parasitism of the chebachok, Pseudorasbora parva, in fish ponds. Journal of Ichthyology 27: 180182.

Yan Y., Chen Y. 2009. Variations in reproductive strategies between one invasive population and two native populations of Pseudorasbora parva. Current Zoology 55 (1): 56-60.

Záhorská E., Kováč V. 2009. Reproductive parameters of invasive topmouth gudgeon Pseudorasbora parva (Temminck and Schlegel, 1846) from Slovakia. Journal of Applied Ichthyology 25 (4): 466-469. DOI: 10.1111/j.1439-0426.2009.01190.x

Received: 18 June 2018 Accepted: 25 November 2018 Published electronically: 15 June 2019 